\title{
Subcutaneous emphysema, a different way to diagnose
}

\author{
Bruno José da Costa Medeiros ${ }^{1 *}$ (0) \\ ${ }^{1}$ General Surgery Degree from Fundação Hospital Adriano Jorge (FHAJ). Instituto de Cirurgia do Estado do Amazonas (Icea), Amazonas, AM, Brazil
}

Study conducted at Instituto de Cirurgia do Estado do Amazonas (Icea), Amazonas, AM, Brazil

Article received: $4 / 14 / 2017$ Accepted for publication: $5 / 7 / 2017$

*Correspondence: Address: Rua Rubis, 36 Manaus, AM - Brasil Postal code: 69053-610 brunaojose@bol.com.br

\section{SUMMARY}

Introduction: Subcutaneous emphysema (SE) is a clinical condition that occurs when air gets into soft tissues under the skin. This can occur in any part of the body depending on the type of pathology. The most common site is under the skin that covers the chest wall or neck. It is characterized by painless swelling of tissues. The classic clinical sign is a crackling sensation upon touch, resembling that of touching a sponge beneath your fingers.

Objective: To describe a new way to diagnose subcutaneous emphysema.

Method: Our finding was a matter of serendipity while inspecting a patient with subcutaneous emphysema using a stethoscope. Instead only hearing the patient's chest, the stethoscope was gently pressed against the skin with SE and so we were able to detect a different sound.

Results: This new way to diagnose subcutaneous emphysema consists in pressing the diaphragm part of stethoscope against the patient's skin where SE is supposed to be. Thus, we are able to hear a sound of small bubbles bursting. Crackle noise has an acoustic emission energy that varies between 750-1,200 Hz, considered high frequency.

Conclusion: Although currently the use of imaging methods is widespread worldwide, we would like to strengthen the value of clinical examination. Auscultation is an essential diagnostic method that has become underestimated with the advances of healthcare and medicine as a whole. We therefore propose a different approach to diagnose SE.

Keywords: Subcutaneous Emphysema. Pneumothorax. Thorax.

\section{INTRODUCTION}

In 1834, René Laennec said: "I recalled a well-known acoustic phenomenon: if you place your ear against one end of a wood beam, the scratch of a pin at the other end is distinctly audible".

Subcutaneous emphysema (SE) is a clinical condition that occurs when air gets into soft tissues under the skin. This can occur in any part of the body depending on the type of pathology. The most common site is in the skin that covers the chest wall or neck.

It has a particular characteristic because air travels from its initial location to other sites along the fascia. One of the most common is the travelling of air from the mediastinum to the neck and face along the fascia planes, but it can also travel from the retro peritoneum to the neck or retro peritoneum to scrotum.
The first description was by Laennec in 1819 , who described pneumomediastinum. ${ }^{1}$

The gas entrapped under the skin can result from a lesion on the respiratory or gastrointestinal systems. It often does not need treatment itself, but its presence indicates other possible serious injuries that do require urgent management.

This article discusses the chest and neck presentation only.

\section{Pathophysiology}

The pathophysiology of subcutaneous emphysema originated from the lung involves air leak that may reach subcutaneous plane by means of two different routes:

1. In 1939, in Ontario, Canada, Macklin demonstrated, in a series of experiments on cats and other animals, 
that air leaked from pulmonic alveoli enter pulmonary interstitial space and can travel along the sheaths of pulmonary blood vessels through artificial channels from the lungs to the mediastinum and later to the neck through the fascia planes; ${ }^{2}$

2. The simplest mechanism occurs when the parietal pleura is torn, so that air which has entered the pleural space may pass directly into the chest wall and subcutaneous tissues. ${ }^{3}$

\section{Signs and symptoms}

It is characterized by painless swelling of tissues commonly seen over the chest wall, neck and head, around drain sites (Figure 1) and around wound sites, but it can be seen in any place of the body.

The classic clinical sign is a crackling sensation to the touch, resembling the feeling of touching Rice Krispies or the sensation of having a sponge under the fingers.

Chest pain, sore throat, trouble in swallowing, aching neck, breathlessness and wheezing can be found.

In severe cases, there can be swelling of the entire face and neck sometimes associated with cardiopulmonary symptoms.

\section{Causes}

- Pneumothorax (blunt trauma occurring with a rib fracture or open due to stabbing or gunshot wound and barotrauma).

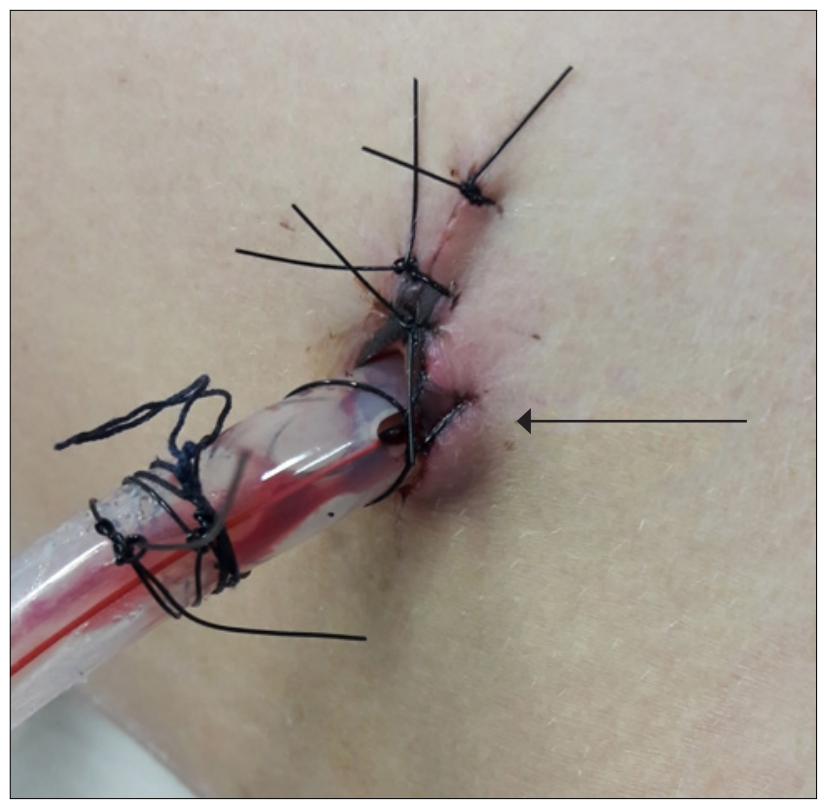

FIGURE 1 The last hole of thoracic drain at the level of the skin predisposing to the appearance of SE.
- Bronchial rupture.

- Esophageal rupture.

- Facial bone fracture.

- Posterior duodenal perforation; in this case, the crackling sensation is identifiable by digital rectal examination.

- Infection in any part of the body, such as gangrene.

- Posterior colon perforation.

- Spontaneous occurrence (while shouting, singing, child birth, violent coughing, straining defecation). ${ }^{4}$

- Following chest tube insertion, tracheal intubation and surgical procedures in upper gastrointestinal tract.

- Complication of asthma from nebulization of bronchodilators.

\section{Diagnosis}

The diagnosis of subcutaneous emphysema is simple due to its characteristic signs and symptoms, but elucidating the primary cause is sometimes difficult and requires an imaging method.

\section{Chest radiograph}

Subcutaneous emphysema may be seen as radiolucent area on soft tissue (Figure 2), which is the most common way of finding it. Sometimes, striations are noticed in the pattern expected from the pectoralis major muscle group (Figure 3), which is called ginkgo leaf sign of the chest. The air that outlines the fibers of the pectoralis major muscle creates a pattern that resembles the veins of a ginkgo leaf (Figure 4).

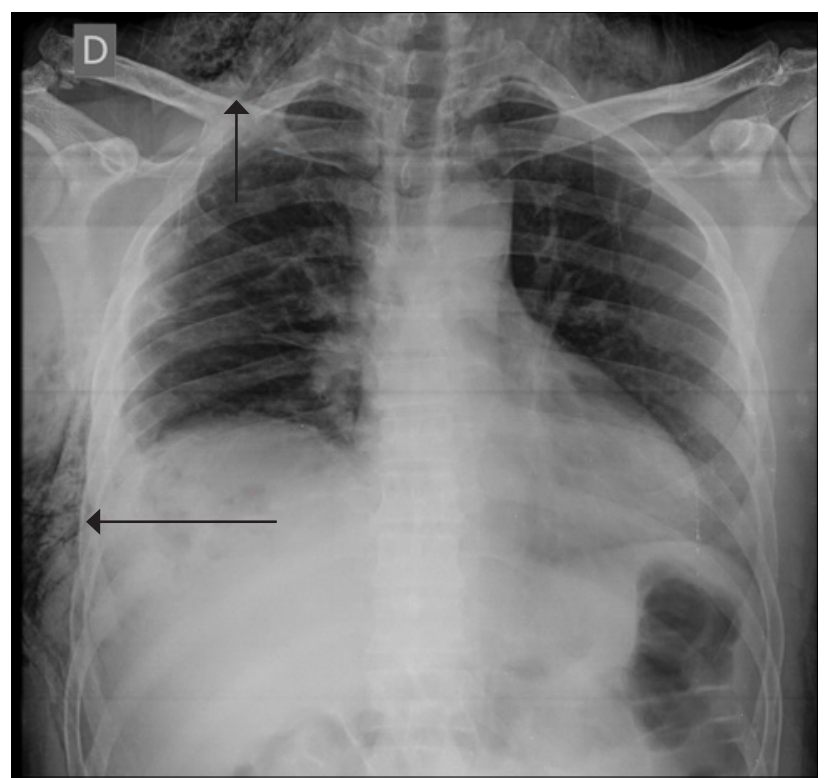

FIGURE 2 Subcutaneous emphysema on X-ray: arrows show SE at right side of chest and at supraclavicular site. 


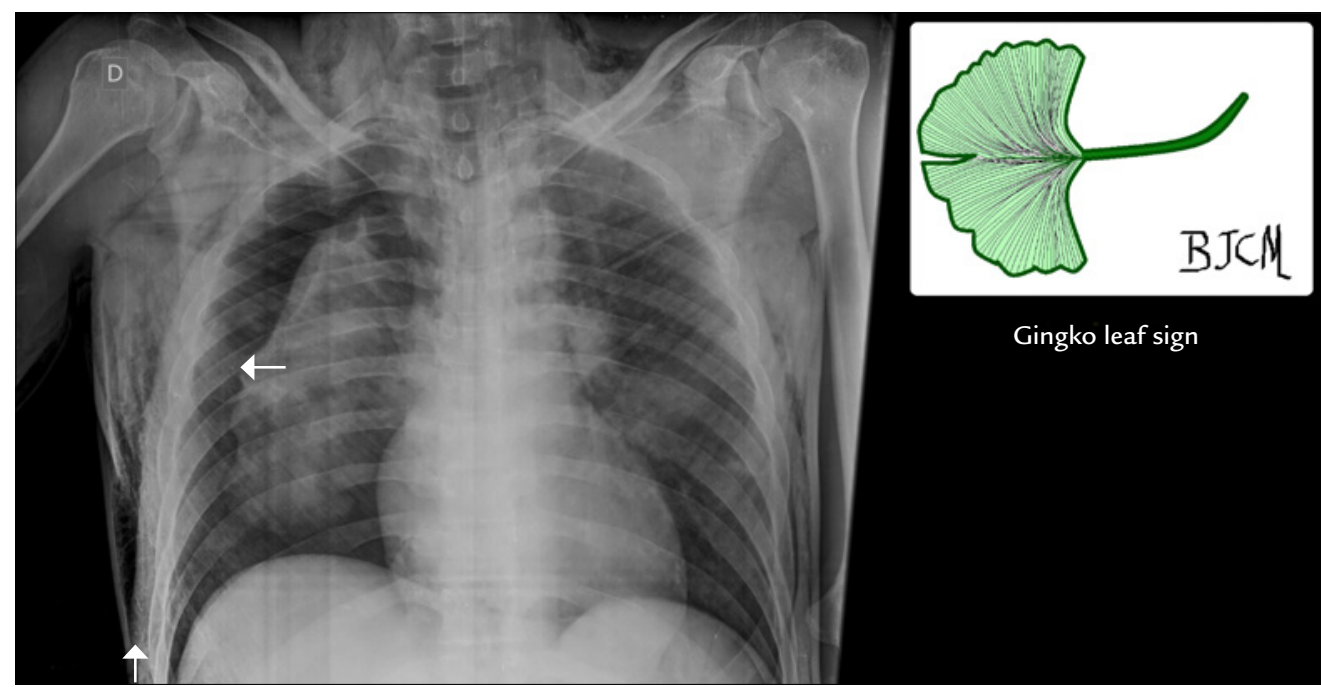

FIGURE 3 Gingko Leaf Sign: observe the air that outlines the fibers of the pectoralis major muscle. The upper arrow indicates a pneumothorax. Bottom arrow indicates SE on right chest.

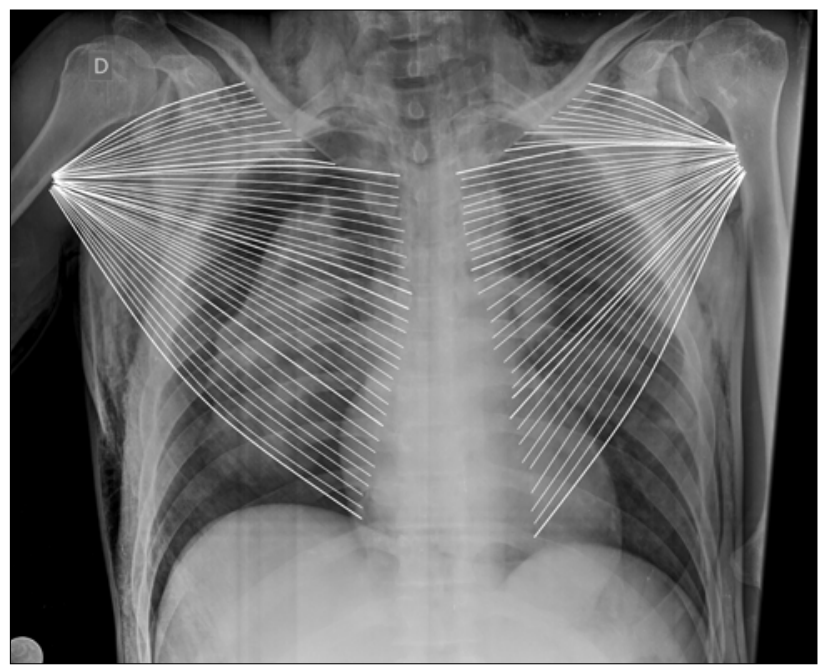

FIGURE 4 The pattern of pectoralis major muscle outlined by the air.

\section{Computed tomography (CT scan)}

Air trapped in subcutaneous tissue appears as dark spots on CT scan. It is easier to see than in the X-ray (Figure 5).

\section{Classification for severity}

In 2013, Aghajanzadeh et al..$^{5}$ classified subcutaneous emphysema into five grades according to severity: grade 1 , base of the neck; grade 2 , all of neck area; grade 3 , sub pectoralis major area; grade 4 , chest wall and all of the neck area; and grade 5, chest wall, neck, orbit, scalp, abdominal wall, upper limbs and scrotum. ${ }^{5}$

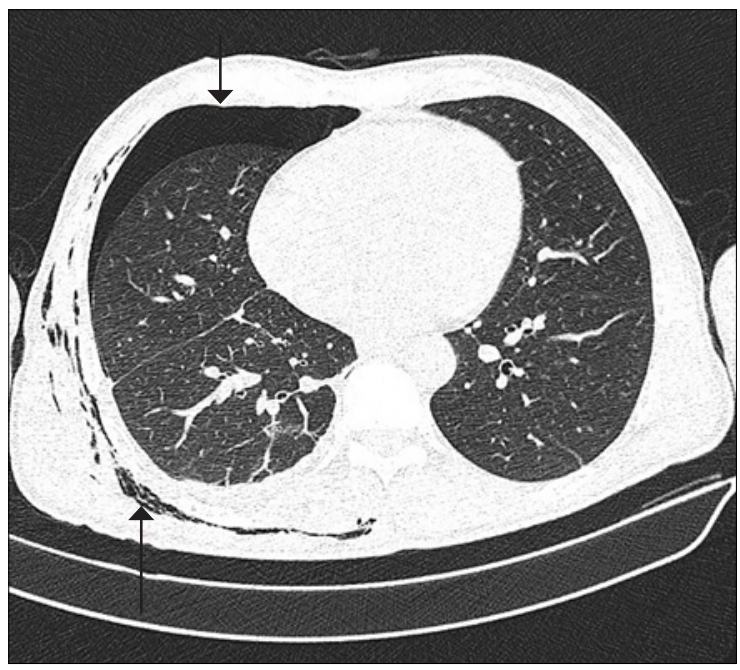

FIGURE 5 Bottom arrow indicates the SE at computed tomography. Upper arrow indicates a pneumothorax.

\section{Treatment}

The treatment of subcutaneous emphysema itself is expectant: controlling the main cause solves this situation, for example: properly inserting a chest tube to treat pneumothorax and making sure that the last hole of the tube is inside the pleural space; closing bronco pleural fistulas; surgically treating and removing skin infections that can cause gangrene; properly draining and correcting ruptured esophagus.

Three types of treatment have been proposed for subcutaneous emphysema with cardiac and respiratory involvement: 
1. The drain is positioned in subcutaneous space through blunt dissection in the compromised chest (midclavicular line, midway between the clavicle and nipple) and later connected to a vacuum device at low pressure $\left(5 \mathrm{cmH}_{2} \mathrm{O}\right)$. This was suggested in case of extensive disease with airway and cardiovascular compromise by compression of structures in the neck. ${ }^{6}$

2. Use of subcutaneous incisions to decompress massive spontaneous subcutaneous emphysema to neck and head with no obviously remediable intrathoracic process. Bilateral $3-\mathrm{cm}$ infraclavicular incisions made down to the pectoralis fascia in these patients with acute decompression and alleviation of the case. ${ }^{7}$

3. Use of needles has been described in the past. ${ }^{8}$

\section{Method}

Search for the articles included in this review was done on the Medline, Lilacs and Cochrane library databases using the Medical Subject Headings (MeSH): subcutaneous emphysema.

The new way to diagnose subcutaneous emphysema was discovered as serendipity during the normal clinical inspection of patients with suspected subcutaneous emphysema. The patients underwent usual clinical inspection: auscultation, inspection, palpation and percussion of chest and neck.

During the clinical exams, instead of only hearing the patient's chest, the stethoscope was gently pressed against the swollen skin with SE, with the purpose of performing a classic clinical examination.

While pressing the stethoscope's diaphragm onto the swollen skin with SE, an incidental finding was noted: a new noise could be detected coming from the skin and not from the lungs or pleural space.

\section{Results}

The result of this incidental finding was a new way to diagnose SE. It consists in pressing the diaphragm part of the stethoscope against the patient's chest, neck or belly, where SE is present.

This way, it is possible to hear the noise of lots of small bubbles bursting. Very audible crepitation comes from the stethoscope. It has an acoustic emission energy that varies between $750-1.200 \mathrm{~Hz}$, which is considered high frequency. ${ }^{9}$

This treble (acute) sound produced can be heard using the diaphragm part of a stethoscope, which was designed to hear acute sounds.

\section{Discussion}

Currently, the use of imaging methods is widespread but we would like to highlight the value of clinical examination. Although auscultation is an essential diagnostic method, it has become underestimated in many cases as healthcare and medicine have advanced. However, it is a simple, noninvasive, quick diagnostic technique and is appropriate to rapidly investigating the pathological condition, and is still very useful for medical care in emergencies and disasters. Making a diagnosis based on auscultation requires sufficient experience. ${ }^{10}$

In this context, we would like to propose a different way to diagnose subcutaneous emphysema. A new diagnostic and qualitative sign.

When a patient has SE, we can feel a crackling sensation in the patient's skin to the touch. This different way to diagnose consists in pressing the diaphragm part of a stethoscope against the patient's chest, neck or belly, and hear small bubbles bursting. Hearing the emphysema is even more sensitive than touching it (Figure 6).

We therefore propose this different and simple manner to diagnose this particular clinical condition.

\section{Conflict of interest}

The author declares no conflict of interest.

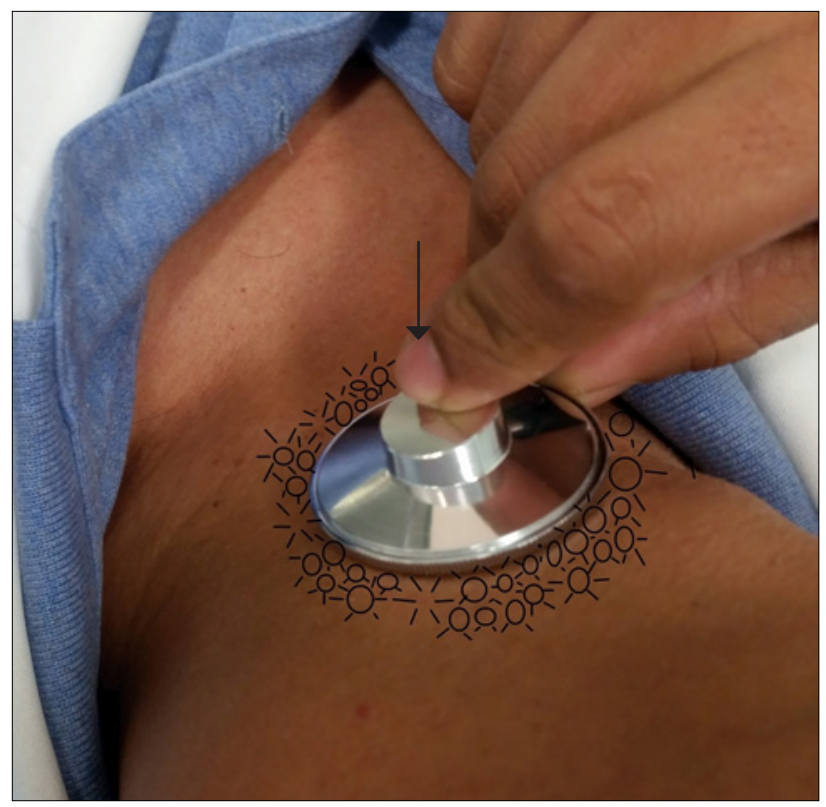

FIGURE 6 When the diaphragm part of the stethoscope is pressed against the skin with $\mathrm{SE}$, is possible to hear the noise of small bubbles bursting. 


\section{Resumo}

Enfisema subcutâneo: uma forma diferente de diagnosticar

Introdução: $\mathrm{O}$ enfisema subcutâneo é uma condição clínica que ocorre quando o ar entra nos tecidos sob a pele. Isso pode ocorrer em qualquer parte do corpo, dependendo do tipo de patologia. O local mais comum é sob a pele que cobre a parede torácica ou o pescoço. É caracterizado por inchaço indolor de tecidos. O sinal clínico clássico é a sensação de crepitação quando se toca a região afetada, assemelhando-se à sensação de se tocar uma esponja.

Objetivo: Descrever uma nova maneira de diagnosticar enfisema subcutâneo.

Método: Este achado foi uma serendipidade, caracterizada por inspeção clínica de pacientes com enfisema subcutâneo com uso de estetoscópio. Além da auscultação do tórax do paciente, o estetoscópio foi suavemente pressionado contra a pele com enfisema subcutâneo, sendo possível detectar um ruído diferente.

Resultados: Essa nova maneira de diagnosticar enfisema subcutâneo consiste em pressionar o diafragma do estetoscópio contra a pele do paciente supostamente afetada por enfisema subcutâneo, sendo possível ouvir o ruído de pequenas bolhas estourando. O ruído de crepitações tem uma energia de emissão acústica que varia de 750-1.200 Hz, considerada alta frequência.

Conclusão: Atualmente, o uso de métodos de imagem é generalizado em todo o mundo, mas gostaríamos de fortalecer o valor do exame clínico. Embora a ausculta seja um método de diagnóstico essencial, foi subestimado à medida que os cuidados de saúde e os medicamentos avançaram. Propomos uma maneira diferente de diagnosticar enfisema subcutâneo.

Palavras-chave: Enfisema Subcutâneo. Pneumotórax. Tórax.

\section{References}

1. Roguin A. Rene Theophile Hyacinthe Laënnec (1781-1826): the man behind the stethoscope. Clin Med Res. 2006; 4(3):230-5.

2. Maes S, Van Goethem B, Saunders J, Binst D, Chiers K, Ducatelle R. Pneumomediastinum and subcutaneous emphysema in a cat associated with necrotizing bronchopneumonia caused by feline herpesvirus-1. Can Vet J. 2011; 52(10):1119-22.

3. Abu-Omar Y, Catarino PA. Progressive subcutaneous emphysema and respiratory arrest. J R Soc Med. 2002; 95(2):90-1.

4. Shankar PS. Subcutaneous emphysema from bronchocavitary subcutaneous fistula. Lung India. 2008; 25(2):73-4

5. Aghajanzadeh M, Dehnadi A, Ebrahimi H, Fallah Karkan M, Khajeh Jahromi S, Amir Maafi A, et al. Classification and management of subcutaneous emphysema: a 10-year experience. Indian J Surg. 2015; 77(Suppl 2):673-7.

6. O'Reilly P, Chen HK, Wiseman R. Management of extensive subcutaneous emphysema with a subcutaneous drain. Respirol Case Rep. 2013; 1(2):28-30

7. Herlan DB, Landreneau RJ, Ferson PF. Massive spontaneous subcutaneous emphysema. Acute management with infraclavicular "blow holes". Chest. 1992; 102(2):503-5

8. Nair KK, Neville E, Rajesh P, Papaliya H. A simple method of palliation for gross subcutaneous surgical emphysema. J R Coll Surg Edinb. 1989; 34(3):163-4.

9. Kiyokawa H, Yonemaru M, Horie S, Ichinose Y, Toyama K. [Frequency analysis of crackles recorded with a stethoscope-equipped recorder]. Nihon Kyobu Shikkan Gakkai Zasshi. 1995; 33(12):1341-7.

10. Hayashi N. Detection of pneumothorax visualized by computer analysis of bilateral respiratory sounds. Yonago Acta Med. 2011; 54(4):75-82. 